\title{
Molecular strategies for the differentiation and identification of local E. coli isolated from chicken: I. Characterization of protein profile.
}

\author{
S. S. Salama*, Afaf A. Kheder, Elham A. Elebiary, M. M. Taha \\ Central Laboratory for Evaluation of Veterinary Biologices, Abbasia, Cairo, Egypt.
}

\begin{abstract}
In this study five serotypes of $E$. coli were isolated from chickens and identified as $\mathrm{O1}, \mathrm{O2}$, O6, 078 and 0126 out of 33 isolates derived from a total of 60 samples. SDS-PAGE revealed that four proteins were characteristic and shared in all these serotypes at the molecular weight of $21,30,55$ and $74 \mathrm{kDa}$ of which 55 and $74 \mathrm{kDa}$ proteins were fully reacted with the antisera against $E$. coli in the western blot. Other proteins are present but varied from one serotype to another.
\end{abstract}

E. coli is one of the serious problems that affect poultry industry because it is responsible for a variety of disease conditions such as colisepticemia, air sacculitis, peritonitis, perihepatitis, pericarditis, omphalitis, salpengitis, coligranuloma and enteritis (Heller et al., 1972; Gross, 1991).

Most strains of E. coli are harmless; however some are pathogenic by virtue of plasmid. Mediated virulence factors through which disease is induced in animals and poultry (Morris and Sojka, 1985; Gyles, 1986).

$E$. coli infection in poultry is usually associated with high economical losses. This is due to high morbidity and mortality rates, decrease food conversion rate, body weight loss, and decrease in egg production, condemnation of whole affected carcass or organs and the high cost of wide range of antibacterial agents used to control. Therefore rapid and accurate mean to differentiate between the different strains of $E$. coli in poultry farms is required.

\section{Materials and Methods}

Isolation of $\boldsymbol{E}$. coli. A total of 60 suspected samples taken from colisepticaemic chickens (cloacal swabs and/or bone marrow) were used in the isolation on nutrient agar and MacConkey agar. The suspected colonies were examined for their colonial morphology, microscopical and biochemical characteristics using the API2.E system (Micro bet GNB $12 \mathrm{~A} \backslash \mathrm{B} \backslash \mathrm{E}, 24 \mathrm{E}$ ).

\footnotetext{
* Corresponding author. Tel.: +20 101800205; fax: +2025701258 .

E-mail address: selimsalame2000@hotmail.com (S.S. Salama).
}

Diagnostic antisera. Four polyvalent and 24 monovalent antisera (SEIKEN- Japan) were used for stereotyping of the E. coli suspected isolates using the technique described by (Edwared and Ewmg, 1972). Polyvalent (1):O1, O26, O86, O111, O119, O127, O128. Polyvalent (2): O44, O55, O125, O126, O146, O166. Polyvalent (3): O6, O27, O78, O148, O159, O168. Polyvalent (4): O2, O11, O87, O127, O142.

Harvesting of isolates. A single bacterial colony from each isolates was streaked onto nutrient agar medium and incubated at $37^{\circ} \mathrm{C}$ for 24 hours then inoculated into tryptic soya broth overnight at $37^{\circ} \mathrm{C}$ with shaking. The cells were harvested by centrifugation at $5000 \mathrm{rpm} / 15 \mathrm{~min}$ using cooling centrifuge. The pellets were washed 3 times with PBS ( $\mathrm{pH} 7.2)$ then resuspended in $5 \mathrm{ml}$ of ice cooled $25 \mathrm{mM}$ Tris HCL $(\mathrm{pH} 7)$ (Chart, 1994).

Preparation of hyperimmune sera. Antisera to F11 and FT E. coli antigens were raised in chickens by intramuscular and subcutaneous injection using modified protocol described by (Condon and Owen, 1982). Isolation and concentration of immunoglobulin have been described in detail by (Owen, 1983).

Total protein analysis. The total protein of samples were prepared as described by (Kishor et al., 1996). Total protein analysis was carried out by using SDS-PAGE and western blot technique.

SDS-PAGE. Extracted protein of the purified bacterial preparation was resolved on discontinuous buffer system composed of $10 \%$ (w/v) acrylamid running gel and 4\% shacking gel (Sambrook et al., 1989). Electrophoresis was carried out at a constant voltage $(100 \mathrm{v})$ until 
Table (1): Isolation, identification and serotyping of $E$. coli from chickens.

\begin{tabular}{cccc}
\hline Cases & $\begin{array}{c}\text { No. of } \\
\text { samples }\end{array}$ & $\begin{array}{c}\text { No. of } \\
\text { isolates }\end{array}$ & Serotypes \\
\hline $\begin{array}{c}\text { Apparently } \\
\text { healthy }\end{array}$ & 17 & 8 & O1(4 isolates), O6 (2 isolates), O78 (2 isolates) \\
$\begin{array}{c}\text { Diseased } \\
\text { Freshly dead }\end{array}$ & 24 & 14 & $\begin{array}{c}\text { O1 (3 isolates), O2 (2 isolates),O6 (3 isolates), } \\
\text { O78 (4 isolates), O126 (2 isolates) }\end{array}$ \\
Total & 19 & 11 & $\begin{array}{c}\text { O1 (2 isolates),O2 (1 isolates),O6 (2 isolates), } \\
\text { O78 (3 isolates), O126 (3 isolates) }\end{array}$ \\
\hline
\end{tabular}

Table (2): protein profiles of different isolated $E$. coli serotypes.

\begin{tabular}{|c|c|c|c|c|c|c|c|}
\hline \multicolumn{3}{|c|}{ Serogroupes } & 01 & $\mathbf{O 2}$ & 06 & 078 & 0126 \\
\hline \multirow{17}{*}{ Protein profile } & \multirow{8}{*}{ common } & $21 \mathrm{kDa}$ & + & + & + & + & + \\
\hline & & $26 \mathrm{kDa}$ & + & - & - & + & + \\
\hline & & $27 \mathrm{kDa}$ & - & + & - & + & + \\
\hline & & $30 \mathrm{kDa}$ & + & + & + & + & + \\
\hline & & $32 \mathrm{kDa}$ & + & + & - & - & + \\
\hline & & $56 \mathrm{kDa}$ & + & + & + & + & + \\
\hline & & $74 \mathrm{kDa}$ & + & + & + & + & + \\
\hline & & $85 \mathrm{kDa}$ & + & - & - & + & + \\
\hline & \multirow{9}{*}{ uncommon } & $24 \mathrm{kDa}$ & + & - & - & - & + \\
\hline & & $40 \mathrm{kDa}$ & - & - & - & + & - \\
\hline & & $60 \mathrm{kDa}$ & + & + & - & - & - \\
\hline & & $64 \mathrm{kDa}$ & - & - & - & + & + \\
\hline & & $67 \mathrm{kDa}$ & - & - & + & - & - \\
\hline & & $69 \mathrm{kDa}$ & - & + & - & - & - \\
\hline & & $78 \mathrm{kDa}$ & - & + & + & - & - \\
\hline & & $95 \mathrm{kDa}$ & + & - & - & - & - \\
\hline & & $100 \mathrm{kDa}$ & - & - & - & - & + \\
\hline
\end{tabular}

tracking dye front (Bromophenol blue) moved to the bottom of the gel.Wide range protein marker (10 kDa to $200 \mathrm{kDa}$, Page Ruler protein Ladder; Fermentas) was used. The gel was stained with SDS-PAGE gel stain (Gel Code Blue Stain, PIERCE, USA.). Molecular weight of each protein band was calculated with reference to a standard curve derived from the migration patterns of the protein molecules weight marker.

Western blot technique. The electrophoretic transfer of the polyacrylamide gel resolved proteins to the nitrocellulose membrane was carried out by electro blotting as described by (Towbin et al., 1979) using Bio Rad Electro Transfer unit. The unoccupied sites on the membrane were blocked with blocking buffer (Tris buffer saline (TBS) pH 7.2, containing 0.1 Tween $20,1 \%(\mathrm{w} / \mathrm{v})$ western blot grade gelatin and $0.05 \%$ triton $\mathrm{x} 100)$. The membrane was then incubated with hyperimmune sera $(1: 100$ in blocking buffer) at $37^{\circ} \mathrm{C}$ for 1 hour followed by three washes with TBS-Tween 20 . The membrane was then incubated at $37^{\circ} \mathrm{C}$ for 1 hour in diluted antichicken peroxidase labeled (1:5000 in TBS-Tween 20) then washed as before and incubated in freshly prepared substrate solution (10 mg aminoethyle carbazone in $50 \mathrm{ml}$ PBS containing 50ul of $30 \% \mathrm{H}_{2} \mathrm{O}_{2}$ ) for 3 - $4 \mathrm{~min}$. for colour development and visible bands were obtained. The reaction was stopped by washing the membrane with running distilled water.

\section{Results}

Only 5 serotypes of $E$. coli represented as $\mathrm{O} 1, \mathrm{O} 2, \mathrm{O} 6, \mathrm{O} 78$ and $\mathrm{O} 126$ were isolated biochemically identified and serogrouped out of 60 different samples as shown in Table (1)

It is clear that only $\mathrm{O} 1, \mathrm{O} 6$ and $\mathrm{O} 78$ serogroups were isolated from the apparently healthy birds while the all 5 recovered serogroups were isolated from either the 


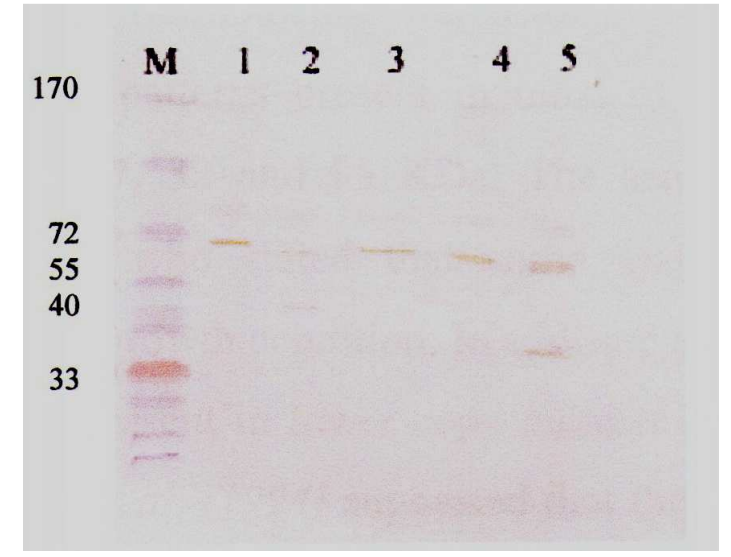

Photo (2). Western blot analysis of total protein of different $E$. coli serotypes. Lane (1):01, Lane (2):O2, Lane (3):06, Lane (4):O78, Lane (5):0126 Lane M: molecular weight protein marker.

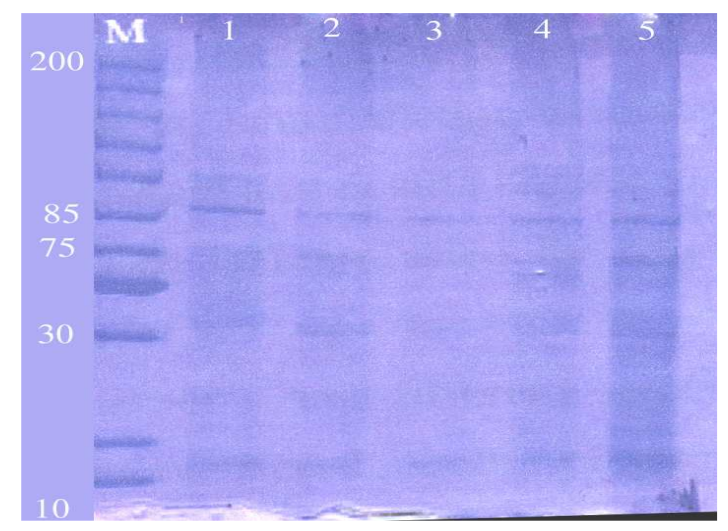

Photo (1). SDS-PAGE of total protein of the five isolated $E$. coli serotypes.

Lane (1):01, Lane (2):02, Lane (3):06, Lane (4):O78, Lane (5):0126

Lane M: molecular weight protein marker.

colisepticaemic or diseased birds.

Regarding the protein profile as shown in the analysis of the SDS-PAGE in Table (2) and Photo (1), there is major common protein patterns of molecular weight $21,30,55$ and 74 $\mathrm{kDa}$ shared in all serotypes also there are other patterns shared in the most of the isolated serotypes like that obtained at 26, 27, 32 and 85 $\mathrm{kDa}$. On the other hand, there were additional protein bands related to each serotypes as shown in Table (2).

Concerning the western blot analysis against E. coli antisera as shown in Photo (2), it is clear that there are two major common epitopes fully reacted with the antisera prepared against $E$. coli at the molecular weight of 55 and $74 \mathrm{kDa}$ other reaction appeared and varied from one serotype to another.

\section{Discussion}

The most common clinical manifestation associated with $E$. coli infection are air saculitis, pericarditis, septicaemia and death (Vidotto et al., 1990). Also colibacillosis due to virulent strains in chicken is manifested by respiratory disease followed by general infection (Gross, 1984).

Although chicken may harbor many different serotypes in their gastrointestinal tract, in the present study, only a restricted number of serotypes (O1, O2, O6, O78 and O126) have been most commonly found (Table 1) .The most predominate serotypes were $\mathrm{O} 1$ and $\mathrm{O} 78$ where each represent nine isolates out of thirty three followed by $\mathrm{O} 126$ (five isolates) then $\mathrm{O} 2$ (four isolates). Similar serotypes (O1, O2, and O78) were obtained by Ibrahim (1997). In addition, Peighambari et.al. (1995) recorded that the most common serogroups of $E$. coli from avian diseases were $\mathrm{O} 78, \mathrm{O} 2$, and $\mathrm{O} 1$ which were associated with septicaemic $E$. coli infection in poultry.

As shown in Table (2) and Photo (1), there are major protein clusters shared in all isolates and appeared at the molecular weight of 21,30 , 55 and $74 \mathrm{kDa}$. Also other common patterns present in most of the isolates obtained at the molecular weight of 26, 27, 32 and $85 \mathrm{kDa}$. The same criteria were reported by Lughtenberg et. al. (1975) who stated that some major proteins of E. coli are predominate under specific growth condition. In addition to the major proteins there are minor proteins which are present in lower copy number and can be detected in SDS-PAGE. Moreover Vidotto et. al. (1994) suggested that the protein of approximately $74 \mathrm{kDa}$ is important for the virulence of $E$. coli strains. On the other hand, Fantinatti et al. (1994) concluded that, the non-pathogenic strains of E.coli lacked two major proteins reported to be correlated either with enterocholin or with aerobactin.

As regards to the immunoreactivity in the western blot analysis, there are two major proteins fully reacted in all serotypes at the molecular weight of 55 and $74 \mathrm{kDa}$. Vidotto et. al. (1994) confirmed these results as they reported that the $74 \mathrm{kDa}$ protein is important and predominate in the E. coli strains. It is clearly that the proteins of 55 and $74 \mathrm{kDa}$ are products of a well-conserved gene and major cross reacting antigens within the $E$. coli serotypes. In this respect, it behaves in a manner similar to several major envelope immunogens.

In conclusion all the results of this study clearly show high discriminating potential of the protein profiles analysis in typing of $E$. coli strains isolated from chickens. The 
differentiation of the isolates from each other by using protein profiles can provide a reliable additional method to aid in the characterization of the bacteria.

\section{References}

Chart, H. (1994): Methods in practical laboratory bacteriology. CRC press, BlveI., N.M., Boca Raton, Florida, U.S.A.

Condon, C. and Owen, P. (1982): Succinate dehydrogenase a major cross-reacting antigen in the enterobacteriacae.FEMS Microbiol. Lett. 15:109-113

Edwaeds. P. R. and Ewing. W. H. C. (1972): Identification of Enterobacteriaceae Minneapolis, Burgess publishing co Burgess publishing co. Atlantal U.S.A J $11^{\text {th }}$ ed. pp.709.

Fantinatti, F.; Silveria, W. D.; and Castro, A. F. P. (1994): Characteristics associated with pathogenicity of avian septicemic E. coli. Vet. Microbiol., 41:75-86.

Gross, R. J. (1984): Acute enteritis. in Toply and Wilson's Principles of Bacteriology, Virology and Immunity. $7^{\text {th }}$ ed. Vol.3. Bacterial disease Butley, Tanner LTd. Forme, pp. 456-476.

Gross, W. B. (1991): Colibacillosis. Diseases of Poultry, 9: 138-144.

Gyles, C. L. (1986): E. coli in: Gyles CL,Thoen Co.,eds pathogenesis of bacterial infection in animals. Ames. Iowa .State Univ. Press, pp. 114-131.

Heller, E. D.; Perer, M.; Damodoran, S. and ThanikaChalam, M. (1972): Coligranuloma in fowls. Ind Vet. J., 49: 32-35.

Ibrahim, I. S. (1997): Prevalence of E. coli in slaughtered broiler and their products. Ph.D. Thesis (meat hygiene),
Fac. Vet. Med. Cairo, Univ. Egypt.

Kishor, L.; Natarajan, K. and Babu, L. R. (1996): Total soluble protein and membrane lipopolysacharide profiles in differentiating Rhizobium isolates. Microbios 86: 143-156. Lugtenberg, B.; Meijers, J.; Peters, R. and VanderHoeck P. (1975): Electrophoretic resolution of the major outer membrane protein of E. coli k-12 into four bands. Fed Europ. Biochem. Soc. Lett., 58: 254-258.

Morris, J. A. and Sojka, W. J. (1985): E. coli as pathogen in animals (The virulence of E. coli) Academic Press, London, pp. 47-77.

Owen, P. (1983): Antigens of the E. coli cell envelope. in O.J. Bjerrum (ed), electro immunochemical analysis of membrane protein. Elsevier science publishers Amsterdam. pp. 347-373.

Peighambari, S. M.; Vallancourt, J. P.; Wilson, R.A and Gyles, C. L. (1995): Characteristics of E. coli isolates from avian cellulites. Avian Dis., 39: 116-124.

Sambrook, J.; Fritsch, E. F. and Maniatis (1989): Molecular coloning a laboratory manual. $2^{\text {nd }}$ ed. cold spring Harbor laboratory press.

Towbing, J.; Stachlin, T. and Gordon, J. (1979): Electrophoretic transfer of proteins from polyacrylamide gels to nitrocellulose. Sheet:procedure and some applications. Proc. Nat. Acad. Sci. USA, 76: 4350-4354.

Vidotto, M. C.;Muller, E. E.; Defreitas, C. I..; Alfieri, A.A.; Guimaraes. I.G. and Santos, D.S. (1990): Virulence factor of avian E. coli. Avian Dis., 34: 531-538.

Vidotto, M. C.; Terra, V. A.; Lima, G. S. C. C.; Alfieri, A. F.; Goese, C. R. and Cocao, J. M. C. (1994): Iron regulated outer membrane proteins of strains of avian septicemic E. coli. Braz. J. Med. Biolog. Res., 27(6):12911297.

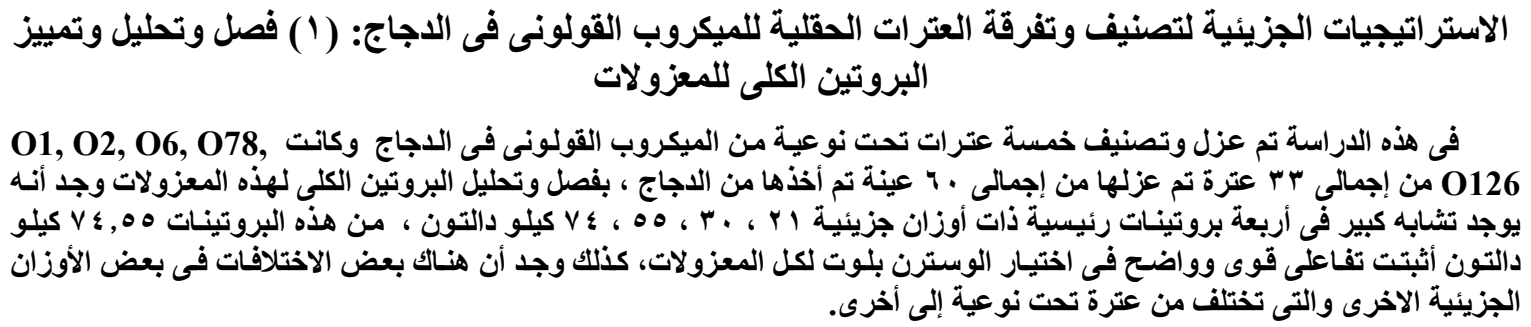

